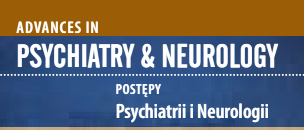

Correspondence to/Adres do korespondencji:

Anna Skórzewska

Institute of Psychiatry and Neurology

9 Sobieskiego St.

02-957 Warsaw, Poland

e-mail: skorzews@ipin.edu.pl

Submitted/Otrzymano: 18.06.2021

Accepted/Przyjęto do druku: 19.07.2021

\section{Glucocorticoid-induced depression - the role of the dopaminergic system and microRNAs}

\author{
Depresja wywołana przez \\ glikokortykoidy - rola układu \\ dopaminergicznego i mikroRNA
}

\author{
Anna Skórzewska (D) \\ Institute of Psychiatry and Neurology, Warsaw, Poland
}

\begin{abstract}
Purpose: Presentation of the role of the dopaminergic system and microRNAs in the development of depression after glucocorticoids (GCs) therapy.

Views: GCs are steroid hormones secreted by the adrenal glands, and their synthesis is regulated by the hypothalamic-pituitaryadrenal (HPA) axis. The secretion of GCs (cortisol in humans and corticosterone in rodents) is dependent directly on corticotropin, secreted from the pituitary gland and indirectly on the corticotropin-releasing factor, a hormone released from the paraventricular nuclei of the hypothalamus. Prolonged treatment with GCs disrupts the functions of the HPA axis, impairs the dopaminergic system, suppresses hippocampal neurogenesis and sensitizes the amygdala, leading to an increased susceptibility to depression. This is an important problem because GCs are commonly prescribed for a broad range of medical conditions, including inflammatory and autoimmune disorders. The action of GCs may be at least partially regulated by epigenetic mechanisms (microRNAs), in addition to which microRNAs modulate GCs production and cellular response to GCs.

Conclusions: The administration of GCs may lead to changes in dopaminergic system activity (e.g. D2 receptors activity), which significantly contribute to the predisposition to depression. Additionally, GCs therapy may cause changes in the activity of microRNAs (e.g. miR-124), which exacerbates symptoms of depression. Searching for specific changes in microRNA expression will provide clinically practical and easily applicable biomarkers of depression risk and new forms of pharmacotherapy in GC-induced depression.
\end{abstract}

Key words: depression, dopaminergic system, microRNA, glucocorticoid therapy.

\title{
Streszczenie
}

Cel: Przedstawienie roli układu dopaminergicznego i mikroRNA w rozwoju depresji wywołanej terapią glikokortykoidami (GCs).

Poglądy: Glikokortykoidy są hormonami steroidowymi wydzielanymi przez nadnercza, a ich synteza jest regulowana przez układ podwzgórze-przysadka-nadnercza (HPA). Sekrecja GCs (kortyzolu u ludzi i kortykosteronu u gryzoni) zależy bezpośrednio od kortykotropiny wydzielanej z przysadki mózgowej oraz pośrednio od czynnika uwalniającego kortykotropinę - hormonu uwalnianego z jąder przyśrodkowych podwzgórza. Długotrwałe leczenie GCs zaburza funkcjonowanie osi HPA, obniża aktywność układu dopaminergicznego, hamuje neurogenezę w hipokampie i aktywuje jądra ciała migdałowatego, prowadząc do zwiększonej podatności na depresję. Jest to ważny problem, ponieważ GCs są powszechnie stosowane w leczeniu licznych schorzeń, m.in. zapalnych i autoimmunologicznych. Działanie GCs może być przynajmniej częściowo regulowane przez mechanizmy epigenetyczne (mikroRNA), jak również mikroRNA modulują produkcję GCs i odpowiedź komórkową na GCs.

Wnioski: Terapia GCs może prowadzić do zmian w aktywności układu dopaminergicznego (m.in. aktywności receptorów D2), które w istotny sposób przyczyniają się do zwiększonej predyspozycji wystąpienia depresji. Dodatkowo terapia GCs może powodować zmiany w aktywności mikroRNA (np. miR-124), co nasila objawy depresji. Poszukiwanie specyficznych zmian w ekspresji mikroRNA pozwoli na uzyskanie praktycznych klinicznie i łatwych do zastosowania biomarkerów depresji oraz nowych form farmakoterapii w depresji wywołanej przez GCs.

Słowa kluczowe: depresja, układ dopaminergiczny, mikroRNA, terapia glikokortykoidami. 


\section{INTRODUCTION}

Synthetic glucocorticoids (GCs) are widely used and highly effective drugs with anti-inflammatory and immunosuppressive effects [1-3]. Nevertheless, GC therapies are associated with severe side effects, including psychiatric effects (depression, mania, psychosis, cognitive and memory impairment) reported in up to $60 \%$ of patients regularly taking them $[4,5]$. The probability of psychiatric side effects is higher with long-term treatment or high doses. Depression tends to occur with long-term GC use, whereas mania can occur much earlier in treatment and is associated with high-doses $[1,3,5]$. The paper aims to discuss the depression associated with long-term GC therapy. Available data suggest several mechanisms of depression, including changes in the serotonergic, noradrenergic, dopaminergic, and glutamatergic systems, increased inflammation, disruption of the hypothalamic-pituitary-adrenal (HPA) axis, and decreased neurogenesis and neuroplasticity [6]. The exact mechanism of glucocorticoidinduced depression is poorly understood. It is known that GC therapy, among others, disrupts HPA axis activity, impairs dopaminergic neurons, suppresses hippocampal neurogenesis, and sensitizes the amygdala. Epigenetic factors are significant for these processes, and therefore in the presented work, these processes will be discussed.

\section{MECHANISM OF GLUCOCORTICOIDS ACTION}

GCs are steroid hormones secreted by the adrenal glands, and their synthesis is regulated by the HPA axis [3]. The secretion of GCs (cortisol in humans and corticosterone in rodents) is dependent directly on corticotropin (adrenocorticotropic hormone - ACTH), secreted from the pituitary gland, and indirectly on corticotropin-releasing factor (CRF), a hormone released from the paraventricular nuclei of the hypothalamus (PVN). In addition to mediating downstream physiological effects, cortisol also provides negative feedback to the HPA axis by inhibiting the release of CRH and ACTH and, subsequently, its secretion [3].

GCs act through two mechanisms: genomic and non-genomic $[2,7,8]$. The classical genomic mechanism of action of GCs is related to glucocorticoid receptors (GR) receptors and mineralocorticoid receptors (MR). GR receptors play an important role in response to a stress factor when the concentration of GCs is high $[2,9]$. MR receptors regulate diurnal variation in GC levels (the diurnal rhythm of the HPA axis) and mediate tonic inhibition of PVN by the hippocampus [10].

In the cytoplasm of the cell, MR and GR receptors are present in an inactive form, linked to proteins including heat shock (proteins that regulate cell survival, differentiation, and death; their expression increases during stress exposure), HSP90 and HSP70 (which prevent the receptor from penetrating from the cytoplasm to the cell nucleus), as well as to a variety of co-chaperones, including FKBP5 (also known as PPIase FKBP5) and BAG1, which mask the nuclear localisation signal $[2,7]$. Once the receptor is combined with GCs, the activated steroid-receptor complex enters the cell nucleus and binds to the hormone response (GRE) DNA sequence [2, 7]. Receptors for GCs, when coupled to GRE, regulate gene expression through direct activation of transcription. Inhibition of gene transcription by GCs receptors has also been shown when combined with so-called "negative GRE" (nGRE) [2, 7]. Gene repression has also been found, independent of DNA, by direct protein interaction ("cross-talk") with other transcription factors: nuclear factor kappa B (NFkB), AP1 factor, nuclear factor of activated $T$ cells (NFAT), and signal transducer and activator of transcription (STAT) $[2,7]$.

In contrast, the mechanism of the non-genomic action of GCs is not clear $[8,11,12]$. Preclinical studies have shown that GCs can produce a rapid effect by reacting with GABAA receptor-dependent chloride channels [13], direct effects on the cell membrane [12], or by activating calcium uptake from the synaptic gap after potassium ion-induced depolarisation [8].

\section{GLUCOCORTICOIDS-INDUCED DEPRESSION - THE ROLE OF micrORNAS}

GCs may also act through epigenetic mechanisms. Epigenetics refers to gene expression that can be modified by environmental or external factors, resulting inheritable characteristics that do not involve changes to the underlying DNA sequence. Thus, it is a change in phenotype without a change in genotype [14]. Epigenetic mechanisms include DNA methylation, histone modifications, nucleosome repositioning, higher-order chromatin remodelling, non-coding RNA (microRNA), and RNA and DNA editing [7]. The GR receptor can locally demethylate DNA at GRE sites, resulting in an increased transcriptional response to dexamethasone in rat hepatoma cells $[7,15]$. Emerging evidence indicates that GCs influence cell proliferation and survival, and function at least in part by regulating microRNA expression; microRNAs also modulate GC production by the adrenal glands and the cells' responses to GCs [16]. MicroRNAs (miRNAs) are small single-stranded non-coding RNA molecules (containing about 22 nucleotides) that can mediate in RNA silencing and post-transcriptional regulation of gene expression $[17,18]$. MicroRNAs function via base-pairing with complementary sequences within mRNA molecules [19]. The binding of microRNAs can decrease the stability of target mRNA or inhibit its translation to downregulate mRNA expression [20]. MicroRNAs occasionally also cause histone modification and DNA 
methylation of promoter sites, which affects the expression of target genes [21, 22]. Both preclinical and clinical studies have demonstrated that miRNAs may contribute to the pathophysiology of depression and the actions of antidepressant drugs [23-25]. In rodents, elevated miR-124-3p levels in the brain were associated with decreased GR levels and increased depression-like symptoms [16, 20]. Dwivedi et al. [23] were the first to show that chronic corticosterone administration to rats caused the altered expression of 26 microRNAs in the prefrontal cortex (19 were upregulated and 7 were downregulated); miR-124 was the most significantly upregulated. Chronic social defeat stress increased miR-124 in the hippocampus, and miR-124a overexpression exacerbated depression-like behaviour. Moreover, selective lentivirus-mediated suppression of miR-124a (miR-124asilencers) in the hippocampus produces antidepressant-like effects in rats [26]. A recent study has indicated that the expression of miR-124-3p is significantly upregulated in the serum of major depressive disorder patients compared with healthy control subjects, which was similar to the results of studies in corticosterone-treated rats and human post-mortem tissue [27]. MicroRNAs also play an essential role in the efficacy of GC therapy. For example, patients with acute lymphoblastic leukemia responding poorly to treatment have been shown to have high miR-124-3p expression accompanied by increased GR receptor expression $[16,28]$. Additionally, the literature suggests possible roles of several other microRNAs (e.g., miR-9, miR-34c, miR-326, miR-494, and miR-504) in processes related to stress and changes in dopaminergic system activity [29-31]. These findings suggest that specific miRNAs may be both a biomarker and therapeutic target for depression related to GC therapy.

\section{GLUCOCORTICOIDS-INDUCED DEPRESSION - THE ROLE OF DOPAMINERGIC SYSTEM}

Long-term GC therapy often leads to depression [5]. Chronic GC administration can induce inducing a decrease in GR receptor sensitivity in the medial prefrontal cortex (PFC) and/or hippocampus and a weakening of the GCs feedback mechanism, which can lead to a decrease in DA release, and consequently induces anhedonia symptoms [32, 33]. Anhedonia (a core symptom of depression) is predominantly characterized by dysfunction in the mesolimbic dopamine (DA) system, which plays a primary role in motivated behaviors [32]. Five dopamine receptors have been identified and classified into D1-like families containing D1 and D5 receptors, and D2-like families including D2, D3, and D4 receptors [34]. The D1-like family induces an increase in cyclic AMP synthesis (cAMP) and dopaminergic neuron activity, while the D2-like family inhibits cAMP synthesis, which correlates with the decreased activity of dopaminergic neurons [35]. Animal studies indicate that anhedonia is functionally associated with a decreased activity of mesolimbic dopamine projections from the ventral tegmental area (VTA) and glutamatergic transmission from the ventromedial prefrontal cortex (PFC) to the nucleus accumbens (NAc) in the ventral striatum [36]. There are multiple reciprocal interconnections between different subregions of the PFC, VTA, NAc, amygdala, and hippocampus, suggesting that these circuits mediate in the behavioral response and development of depression [32]. The hippocampus and PFC play important roles in regulating mood, cognitive function, anxiety, and fear. These structures are the most sensitive brain region to the neurotoxic effects of GCs $[33,37]$. The clinical studies in both healthy and depressed humans show that hippocampal-dependent learning appears to be more sensitive to the effects of cortisol [38]. Additionally, Rocchetti et al. [34] have shown that genetic deletion or the pharmacological blockade of presynaptic D2 receptors in dopaminergic fibres of the temporal hippocampus led to the inhibition of long-term depression (LTD) and play a major role in regulating hippocampal learning and memory. Chronic GC administration also decreased volume, spine density, and reduced activity in the prefrontal cortex, similar to changes observed in depressed patients $[39,40]$.

The amygdala is a brain structure involved in the modulation of emotional processes and HPA axis activity, and GCs play an important role in regulating these processes [41-43]. In humans, higher cortisol levels while viewing emotionally arousing pictures were associated with greater amygdala activation in functional magnetic resonance imaging (MRI) [41]. Furthermore, patients receiving chronic GCs therapy had smaller amygdala volumes than control subjects [43]. The postsynaptic $\mathrm{D} 2$ receptors primarily residing on GABAergic neurons modulate the activity of the amygdala [44]. An increase in dopamine D2 receptor activity in the amygdala attenuates the local inhibitory function, leading to the enhanced neural activity associated with a negative emotional state $[45,46]$. Furthermore, corticosterone treatment enhances the excitability of principal basolateral amygdala (BLA) cells by increasing their intrinsic excitability and decreasing the impact of GABA-A receptor inhibition [42]. Thus, it seems that corticosterone changes in local dopamine $\mathrm{D} 2$ receptors activity coregulate the activity of the GABAergic system in the amygdala. Figure I shows the role of microRNAs and the dopaminergic system in the possible mechanism of GC-induced depression.

\section{PHARMACOLOGICAL TREATMENT OF GLUCOCORTICOIDS-INDUCED DEPRESSION}

The available data concerning the effects of antidepressants in patients taking corticosteroids is limited and 


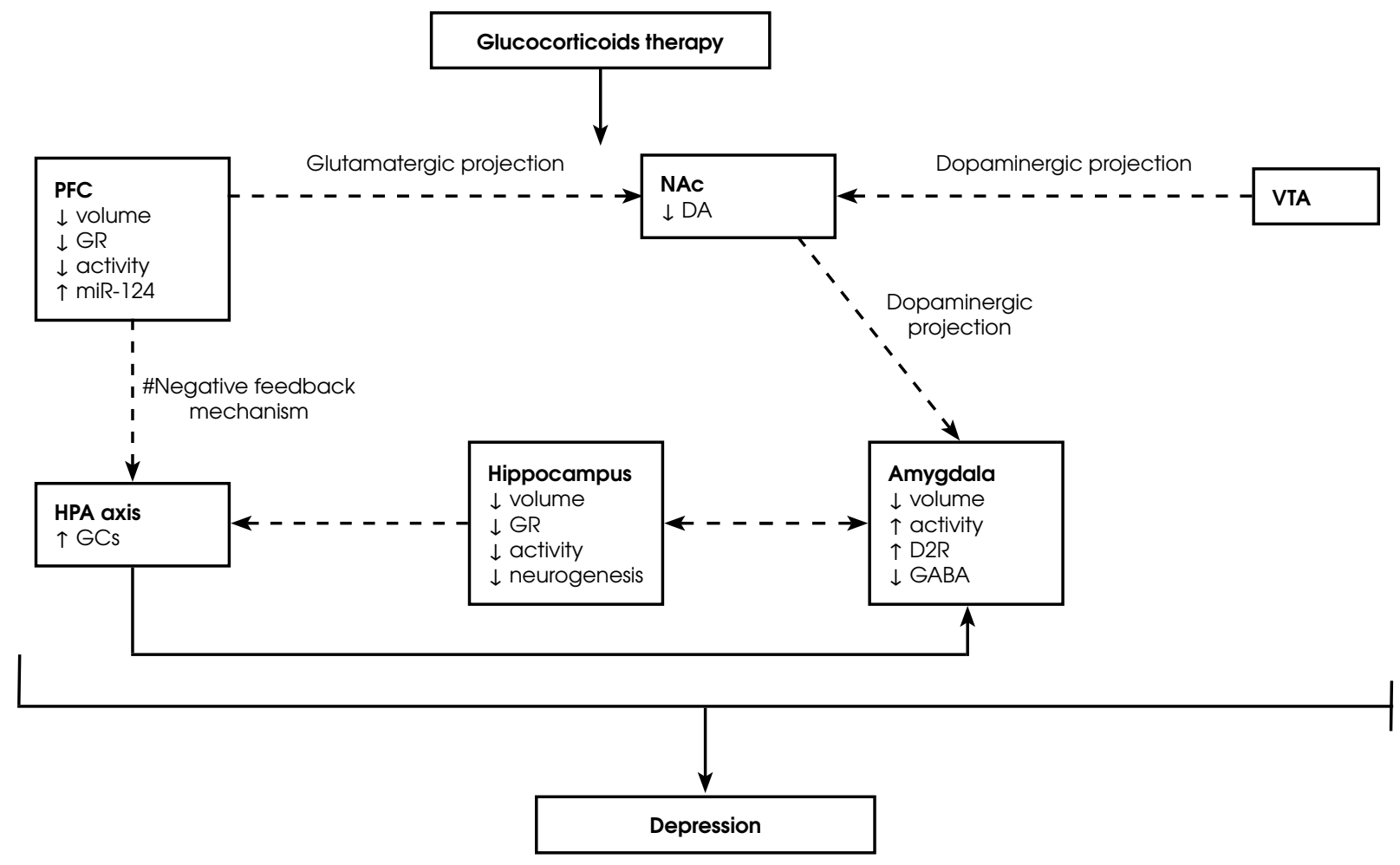

$D A$ - dopamine, D2R-dopamine receptor type 2, GCs-glucocorticoids, HPA axis-hypothalamic-pituitary-adrenal axis, NAc-nucleus accumbens, PFC - prefrontal cortex, VTA - ventral tegmental area, $\uparrow$-increase; $\downarrow$-decrease; dashed line - attenuation; solid line - enhancement.

Figure I. Schematic illustrates the role of microRNAs and the dopaminergic system in the development of depression in subjects subjected to GCs therapy. Long-term GCs therapy leads to a decrease in the activity of the PFC and hippocampus, which consequently impairs the feedback mechanism of the HPA axis and the sustained increase in cortisol. Chronic GCs therapy also attenuates dopaminergic projection from the VTA and glutamatergic projection from the PFC to the NAc, leading to diminished DA release. In addition, increased activity of D2Rs in the amygdala, which lowers the function of the GABAergic system, leading to higher local neuronal activity and enhanced negative emotional state. GCs therapy also induces changes in microRNA expression (e.g. miR-124), which exacerbates depressive symptoms

mixed. Initial treatment of patients with GC-induced depression with tricyclic antidepressants (TCAs) was associated with increased agitation and psychosis [47]. However, studies also show TCA's efficacy in GC-induced depression [48]. The use of selective serotonin inhibitors (sertraline, fluoxetine, or fluvoxamine) was effective in treating depressive symptoms associated with GCs use [49-51]. Additionally, administration of olanzapine (an atypical antipsychotic, multi-target block drug) during GC therapy was successful in the treatment of subacute mood changes $[5,52]$.

\section{CONCLUSIONS}

Synthetic GCs, due to the broad spectrum of their activity, are used in many diseases, but they often cause adverse effects, including depression. The mechanism of GC-induced depression is unclear. Available data suggest that the dopaminergic system impaired by long-term GC administration and epigenetic mechanisms, especially microRNAs, may play an important role in these processes. Special attention is directed to the search for specific changes in microRNA expression that will provide clinically practical and easily applicable biomarkers of depression risk and new forms of pharmacotherapy in GC-induced depression. 
Glucocorticoid-induced depression - the role of the dopaminergic system and microRNAs

Depresja wywołana przez glikokortykoidy - rola układu dopaminergicznego i mikroRNA

\section{Conflict of interest/Konflikt interesu}

Absent./Nie występuje.

Financial support/Finansowanie

Absent./Nie występuje.

\section{References/Piśmiennictwo}

1. Kenna HA, Poon AW, de los Angeles CP, Koran LM. Psychiatric complications of treatment with corticosteroids: review with case report. Psychiatry Clin Neurosci 2011; 65: 549-560.

2. Vandewalle J, Luypaert A, De Bosscher K, Libert C. Therapeutic mechanisms of glucocorticoids. Trends Endocrinol Metab 2018; 29: 42-54.

3. Scherholz ML, Schlesinger N, Androulakis IP. Chronopharmacology of glucocorticoids. Adv Drug Deliv Rev 2019; 151-152: 245-261.

4. West S, Kenedi C. Strategies to prevent the neuropsychiatric side-effects of corticosteroids: a case report and review of the literature. Curr Opin Organ Transplant 2014; 19: 201-208.

5. Kusljic S, Manias E, Gogos A. Corticosteroid-induced psychiatric disturbances: it is time for pharmacists to take notice. Res Social Adm Pharm 2016; 12: 355-360.

6. Dean J, Keshavan M. The neurobiology of depression: an integrated view. Asian J Psychiatr 2017; 27: 101-111.

7. Gray JD, Kogan JF, Marrocco J, McEwen BS. Genomic and epigenomic mechanisms of glucocorticoids in the brain. Nat Rev Endocrinol 2017; 13: 661-673.

8. Panettieri RA, Schaafsma D, Amrani Y, Koziol-White C, Ostrom R, Tliba O. Non-genomic effects of glucocorticoids: an updated view. Trends Pharmacol Sci 2019; 40: 38-49.

9. Reul JM, Holsboer F. On the role of corticotropin-releasing hormone receptors in anxiety and depression. Dialogues Clin Neurosci 2002; 4: 31-46.

10. Heuser I, Lammers CH. Stress and the brain. Neurobiol Aging 2003; 24 Suppl 1: S69-S76; discussion S81-S82.

11. Falkenstein E, Wehling M. Nongenomically initiated steroid actions. Eur J Clin Invest 2000; 30 Suppl 3: 51-54.

12. Stellato C. Post-transcriptional and nongenomic effects of glucocorticoids. Proc Am Thorac Soc 2004; 1: 255-263.

13. Majewska MD. Steroids and brain activity. Essential dialogue between body and mind. Biochem Pharmacol 1987; 36: 3781-3788.

14. Smith D. Epigenetics. In: Kreutzer J, DeLuca J, Caplan B (eds.). Encyclopedia of Clinical Neuropsychology. Cham: Springer; 2017.

15. Thomassin H, Flavin M, Espinás ML, Grange T. Glucocorticoid-induced DNA demethylation and gene memory during development. EMBO J 2001; 20: 1974-1983.

16. Clayton SA, Jones SW, Kurowska-Stolarska M, Clark AR. The role of microRNAs in glucocorticoid action. J Biol Chem 2018; 293: 1865-1874.

17. Higuchi F, Uchida S, Yamagata H, Abe-Higuchi N, Hobara T, Hara K, et al. Hippocampal microRNA-124 enhances chronic stress resilience in mice. J Neurosci 2016; 36: 7253-7267.

18. Bartel DP. Metazoan microRNAs. Cell 2018; 173: 20-51.

19. Bartel DP. MicroRNAs: target recognition and regulatory functions. Cell 2009; 136: 215-233.

20. Wang SS, Mu RH, Li CF, Dong SQ, Geng D, Liu Q, et al. microRNA-124 targets glucocorticoid receptor and is involved in depression-like behaviors. Prog Neuropsychopharmacol Biol Psychiatry 2017; 79: 417-425.

21. Hawkins PG, Morris KV. RNA and transcriptional modulation of gene expression. Cell Cycle 2008; 7: 602-607.

22. Tan Y, Zhang B, Wu T, Skogerbø G, Zhu X, Guo X, et al. Transcriptional inhibiton of Hoxd4 expression by miRNA-10a in human breast cancer cells. BMC Mol Biol 2009; 10: 12.

23. Dwivedi Y. Pathogenetic and therapeutic applications of microRNAs in major depressive disorder. Prog Neuropsychopharmacol Biol Psychiatry 2016; 64: 341-348.

24. Issler O, Chen A. Determining the role of microRNAs in psychiatric disorders. Nat Rev Neurosci 2015; 16: 201-212.

25. Kocerha J, Dwivedi Y, Brennand KJ. Noncoding RNAs and neurobehavioral mechanisms in psychiatric disease. Mol Psychiatry 2015; 20: 677-684.

26. Bahi A, Chandrasekar V, Dreyer JL. Selective lentiviral-mediated suppression of microRNA124a in the hippocampus evokes antidepressants-like effects in rats. Psychoneuroendocrinology 2014; 46: 78-87.

27. Roy B, Dunbar M, Shelton RC, Dwivedi Y. Identification of microRNA-124-3p as a putative epigenetic signature of major depressive disorder. Neuropsychopharmacology 2017; 42: 864-875.

28. Liang YN, Tang YL, Ke ZY, Chen YQ, Luo XQ, Zhang H, et al. MiR-124 contributes to glucocorticoid resistance in acute lymphoblastic leukemia by promoting proliferation, inhibiting apoptosis and targeting the glucocorticoid receptor. J Steroid Biochem Mol Biol 2017; 172: 62-68.

29. Zhang Y, Wang Y, Wang L, Bai M, Zhang X, Zhu X. Dopamine receptor D2 and associated microRNAs are involved in stress susceptibility and resistance to escitalopram treatment. Int J Neuropsychopharmacol 2015; 18: pyv025.

30. De Gregorio R, Pulcrano S, De Sanctis C, Volpicelli F, Guatteo E, von Oerthel L, et al. miR-34b/c regulates Wnt1 and enhances mesencephalic dopaminergic neuron differentiation. Stem Cell Reports 2018; 10: 1237-1250. 
31. Kołosowska K, Gawryluk A, Wisłowska-Stanek A, Liguz-Lęcznar M, Hetmańczyk K, Ługowska A, et al. Stress changes amphetamine response, D2 receptor expression and epigenetic regulation in low-anxiety rats. Prog Neuropsychopharmacol Biol Psychiatry 2019; 93: 256-268.

32. Lamontagne SJ, Melendez SI, Olmstead MC. Investigating dopamine and glucocorticoid systems as underlying mechanisms of anhedonia. Psychopharmacology (Berl) 2018; 235: 3103-3113.

33. Sedaghat K, Yousefian Z, Vafaei AA, Rashidy-Pour A, Parsaei H, Khaleghian A, et al. Mesolimbic dopamine system and its modulation by vitamin $\mathrm{D}$ in a chronic mild stress model of depression in the rat. Behav Brain Res 2019; 356: 156-169.

34. Rocchetti J, Isingrini E, Dal Bo G, Sagheby S, Menegaux A, Tronche F, et al. Presynaptic D2 dopamine receptors control long-term depression expression and memory processes in the temporal hippocampus. Biol Psychiatry 2015; 77: 513-325.

35. Gryz M, Lehner M, Wisłowska-Stanek A, Płaźnik A. Dopaminergic system activity under stress condition - seeking individual differences, preclinical studies. Psychiatr Pol 2018; 52: 459-470.

36. Der-Avakian A, Markou A. The neurobiology of anhedonia and other reward-related deficits. Trends Neurosci 2012; 35: 68-77.

37. Abercrombie HC, Jahn AL, Davidson RJ, Kern S, Kirschbaum C, Halverson J. Cortisol's effects on hippocampal activation in depressed patients are related to alterations in memory formation. J Psychiatr Res 2011; 45: 15-23.

38. Hinkelmann K, Moritz S, Botzenhardt J, Riedesel K, Wiedemann K, Kellner M, Otte C. Cognitive impairment in major depression: association with salivary cortisol. Biol Psychiatry 2009; 66: 879-885.

39. Dwivedi Y, Roy B, Lugli G, Rizavi H, Zhang H, Smalheiser NR. Chronic corticosterone-mediated dysregulation of microRNA network in prefrontal cortex of rats: relevance to depression pathophysiology. Transl Psychiatry 2015; 5: e682.

40. LeGates TA, Kvarta MD, Thompson SM. Sex differences in antidepressant efficacy. Neuropsychopharmacology 2019; 44: 140-154.

41. LeDoux JE. Emotion circuits in the brain. Annu Rev Neurosci 2000; 23: 155-184.

42. Duvarci S, Pare D. Amygdala microcircuits controlling learned fear. Neuron 2014; 82: 966-980.

43. Brown ES, Woolston DJ, Frol AB. Amygdala volume in patients receiving chronic corticosteroid therapy. Biol Psychiatry 2008; 63: 705-709.

44. Rowniak M, Kolenkiewicz M, Kozlowska A. Parvalbumin, but not calretinin, neurons express high levels of a1-containing $\mathrm{GABA}(\mathrm{A})$ receptors, a7-containing nicotinic acetylcholine receptors and D2-dopamine receptors in the basolateral amygdala of the rat. J Chem Neuroanat 2017; 86: 41-51.

45. Okita K, Ghahremani DG, Payer DE, Robertson CL, Dean AC, Mandelkern MA, et al. Emotion dysregulation and amygdala dopamine D2-type receptor availability in methamphetamine users. Drug Alcohol Depend 2016; 161: 163-170.

46. Lehner MH, Karas-Ruszczyk K, Zakrzewska A, Gryz M, Wislowska-Stanek A, Kolosowska K, et al. Chronic stress changes prepulse inhibition after amphetamine challenge: the role of the dopaminergic system. J Physiol Pharmacol 2018; 69: 475-487.

47. Hall RC, Popkin MK, Kirkpatrick B. Tricyclic exacerbation of steroid psychosis. J Nerv Ment Dis 1978; 166: 738-742.

48. Wada K, Yamada N, Sato T, Suzuki H, Miki M, Lee Y, et al. Corticosteroid-induced psychotic and mood disorders: diagnosis defined by DSM-IV and clinical pictures. Psychosomatics 2001; 42: 461-466.

49. Beshay H, Pumariega AJ. Sertraline treatment of mood disorder associated with prednisone: a case report. J Child Adolesc Psychopharmacol 1998; 8: 187-193.

50. Wyszynski AA, Wyszynski B. Treatment of depression with fluoxetine in corticosteroid-dependent central nervous system Sjögren's syndrome. Psychosomatics 1993; 34: 173-177.

51. Yoshimura R, Ueda N, Nakamura J. Successful treatment of steroid-induced depression with low dosage of fluvoxamine. Aust N Z J Psychiatry 2001; 35: 855-856.

52. Brown ES, Khan DA, Suppes T. Treatment of corticosteroid-induced mood changes with olanzapine. Am J Psychiatry 1999; 156: 968. 